\title{
Torturers' Charter: An Insight into the Castlereagh Diplock Conveyor-Belt System
}

Christy Walsh

There is now widespread recognition of the importance of a process of British demilitarisation if we are to move towards a just and lasting peace. The future of the Royal Ulster Constabulary (RUC) and the fate of political prisoners are central to this process. Indeed, the two issues are inextricably linked, as it has been human rights abuses by the RUC that has led to many people being behind bars. Therefore a brief look at the nature and function of interrogation centres would be useful at this time.

Between 1969 and today, individuals or groups who have opposed the British presence in the Six Counties have been met with the full force of the RUC's huge powers. It has proved extremely difficult for nationalists to secure protection or redress against RUC abuses of their human rights and dignity. A remarkable feature about their lack of success is that the abuses have been high profile, substantial in volume and severity, and sustained in frequency over the years, with the tacit approval of the British government.

From the mid-1970s, the main RUC interrogation centres such as Castlereagh or Gough barracks became synonymous with torture. It was these centres that were charged with the extrication of 'confessions' through whatever means necessary. During the 1971 Guinea Pig experiments, (in which eleven men were tortured by British intelligence to find out the best methods of breaking a human being, physically and psychologically), the British learned that the removal and isolation of a suspect was an absolute prerequisite to the extraction of a 'confession.' Under the Emergency Provisions Act (EPA), the RUC have the powers to detain a person incommunicado: no contact with a solicitor, family, friends, even talking to other prisoners is not allowed. Children as young as ten can be detained under the EPA, and this has been strongly criticised by the UN committee on the human rights of the child.

These seven days allowed ample time for the extraction of a 'confession.' A report compiled in 1992 by the Haldane Society of Socialist Lawyers found that 90\% of all defendants in Diplock courts have made confessions. These courts not only accept such forced confessions but actively encourage the illtreatment of detainees. For example, the onus of proof in the case of forced confessions is on the defendant, whose word is rarely accepted by judges even when there is substantial medical evidence to support the allegations of torture. Consequently, in the late 1970 s, $97 \%$ of convictions were based wholly or mostly on uncorroborated confessions. This encouraged the RUC, as a matter of operational policy, to extract confessions rather than to focus on the evidence 
against a suspect. However, the most blatant example of judicial encouragement of ill-treatment is the notorious judgement of Lord Justice McGonigal in May 1977. He distinguished between acts of torture and brutality prohibited by the European convention and mundane ill-treatment, arguing that 'a certain roughness of treatment' including 'slaps or blows of the hand on the head or face' was permissible. He ruled that an interrogator may 'use a moderate degree of physical maltreatment for the purpose of inducing a person to make a statement.' This judgement became known in sections of the legal profession as the 'torturers' charter,' and it was an important development in the creation of a hostile, psychological atmosphere in interrogation centres.

Beatings and torture became part of administrative policy. The catalogue of horrors was widespread and staggering. Father Denis Paul and Father Raymond Murray produced a pamphlet, Castlereagh File (1978), in which some 25 methods of torture used as normal practice are listed, including: pulling of hair, beatings, strangulation, hooding until the victim is asphyxiated, forcing a person to stand in a fixed position against a wall for extended periods, pouring freezing liquid into the ears, simulated execution by clicking a gun behind the victim's head, torture by electrocution, cigarette burns, forcing a person to do exercises until point of exhaustion, threats to set the prisoners up for assassination, and a whole series of degradations. Among degrading treatments imposed on the victim were: making prisoners lick up spittle or vomit off the floor and forcing them to imitate an animal such as a horse as the interrogators sat on his back. Women detainees in Castlereagh also experienced sexual abuse; the threat of rape; and obscene, intimidatory language.

However these tactics of torture are being constantly refined over the years, the RUC have learned that beating a detainee senseless does not always produce the most effective results. Thus, physical and psychological torture are corelatives. Although physical torture may not always be applied, the threat of its use is ever-present. Everything contributes to make it so: the dimly lit and empty corridors; the gloomy behaviour of the silent guard; the interrogators' loud and authoritative commands; the direct murder threats made against the detainee's family, in some cases threatening to show the detainee morgue photographs of a previously murdered relative; the display of personal family items taken from the detainee's home (confirming they have the power to breach the sanctity of the home). All these things add to the detainee's sense of vulnerability and fear.

In a recently released report by the Council of European Committee for the Prevention of Torture, this point has been addressed. They state that detainees in RUC custody, 'run a significant risk of psychological forms of ill-treatment.' They also question the whole reasoning behind incommunicado detention and feel that all detainees should be allowed some degree of legal advice upon their arrest (at present they must wait forty-eight hours). Interestingly, although supporting reforms like the electronic recording of RUC interrogations, the committee's recommendations on Castlereagh is that it be closed down on the 
grounds that, those being interrogated there, run 'a significant risk' of physical and psychological torture. They are highly critical of the conditions afforded to detainees, which at times amount to sensory deprivation: no natural light in cells; no fresh water or toilet facilities in cells; disruption of sleep or rest due to the cell light being left on $\mathbf{2 4}$ hours a day; disturbing noise levels; no radio or reading material permitted for mental stimulation; detainees not permitted cigarettes, sweets, or fruit; no exercise permitted; being kept incommunicado from family and legal advice. These are all factors in the mental well being (or otherwise) of someone in Castlereagh, before consideration is even given to the degrees of oppression and coercion that detainees come under while being interrogated.

Given the sophistication of psychological torture and the risks of physical torture while detained incommunicado, it is extremely alarming that there are no safeguards to protect a detainee against being compelled to make a false, self-incriminating statement. This is especially significant considering that $90 \%$ of Diplock court decisions of guilt or innocence are not based on the truth, but on a detainee's lack of fortitude while under several days of physical torture in Castlereagh. While the Committee for the Prevention of Torture are quite right in calling for the closure of Castlereagh, it must be part of a process whereby the legal framework for torture (the EPA and Diplock courts) are dismantled, the RUC is disbanded, and the victims of torture are released from jail. 